\title{
Akuntabilitas Pengelolaan Keuangan Masjid Melalui Penggunaan Buku Kas Dan Formulir Bernomor Urut Tercetak
}

\author{
Nur Fitriyah, Alamsyah, Bambang \\ Jurusan Akuntansi, Fakultas Ekonomi dan Bisnis, Universitas Mataram
}

\begin{abstract}
Kata Kunci: akuntabilitas, manajemen keuangan, buku kas, formulir nomor tercetak, masjid
\end{abstract}

\begin{abstract}
Abstrak:
Masjid tidak hanya digunakan sebagai tempat ibadah saja, tetapi juga digunakan sebagai pusat aktivitas umat Islam dalam berbagai bidang. Hal tersebut menjelaskan esensi dibangunnya masjid adalah sebagai pusat kegiatan umat dan kesejahteraan masyarakat. Semakin kompleks dan pelik permasalahan masyarakat, menuntut masjid agar dapat mengakomodir kebutuhan sosial. Oleh karena itu diperlukan adanya pengelolaan yang baik. Pengelolaan masjid yang baik ditopang dengan pengelolaan keuangan yang baik. Berbagai program yang direncanakan tidak dapat sesuai harapan jika tidak didukung dengan keuangan yang kuat dan sehat. Pengabdian ini bertujuan untuk memberikan edukasi kepada pengelola masjid untuk menggunakan buku kas dan formulir yang bernomor urut tercetak dalam mengelola keuangan masjid dalam rangka meningkatkan akuntabilitas informasi sehingga para donator menjadi lebih percaya kepada pengelola dana masjid yang amanah dan didukung oleh pencatatan yang lengkap walaupun dalam bentuk yang masih sederhana. Metode pengabdian ini ada dua tahap, yaitu 1) tahap ceramah sebagai tahap awal bagi pengelola masjid yang pada umumnya kurang memahami istilah-istilah dalam akuntansi 2) tahap kedua berupa pelatihan dan pendampingan secara langsung dalam membuat pembukuan sederhana dengan menggunakan buku kas dan formulir yang bernomor urut tercetak. Hasil pengabdian ini dapat dipahami dan diterima dengan baik oleh pengelola dana masjid/musholla yang berlokasi di Desa Midang Kecamatan Gunung Sari Kabupaten Lombok Barat dengan output masjid memiliki buku kas dan formulir yang bernomor urut tercetak.
\end{abstract}

\section{Korespondensi: fitriunram@gmail.com}

\section{PENDAHULUAN}

Indonesia merupakan negara dengan populasi muslim terbesar di dunia, dengan jumlah penduduk muslim sebanyak 222 juta jiwa atau sebesar $87 \%$ dari total penduduk (muslimpro.com). Dengan jumlah populasi muslim tersebut, tentu harus didukung oleh jumlah tempat ibadah/masjid yang memadai. Bapak Jusuf Kalla sebagai Ketua Dewan Masjid Indonesia mengatakan bahwa ada 800.000 masjid yang tersebar di seluruh Indonesia (nasional.tempo.co). Lombok sebagai salah satu daerah di propinsi Nusa Tenggara baratpun menjadi salah satu wilayah dengan mayoritas muslim sehingga tidak heran jika Lombok menyandang predikat sebagai Pulau Seribu Masjid. Hal ini didukung oleh data bahwa dari 518 desa kantong hunian di Lombok terdapat 3.676 masjid desa yang besar (jami') dan 5.184 masjid dusun dengan ukuran lebih kecil. Jika ditotal jumlah masjid di Lombok mencapai 8.951 masjid atau hampir 9 ribu masjid. (www.republika.co.id) 
Masjid tidak hanya digunakan sebagai tempat ibadah saja, tetapi juga digunakan sebagai pusat aktivitas umat Islam dalam berbagai bidang. Hal tersebut menjelaskan esensi dibangunnya masjid adalah sebagai pusat kegiatan umat muslim untuk kekuatan Islam dan kesejahteraan masyarakat. Semakin kompleks dan pelik permasalahan masyarakat, menuntut masjid agar dapat mengakomodir kebutuhan sosial. Oleh karena itu diperlukan adanya pengelolaan yang baik. Pengelolaan masjid yang baik ditopang dengan pengelolaan keuangan yang baik. Berbagai program yang direncanakan tidak dapat sesuai harapan jika tidak didukung dengan keuangan yang kuat dan sehat. Artinya, perlu adanya pengelolaan keuangan yang baik (Sochimin, 2015). Hal ini dikarenakan sebagian besar dana masjid berasal dari donasi jamaahnya, seperti yang diungkapkan Wahab (2008) dalam (Sochimin, 2015) jika keuangan masjid tidak dikelola dengan baik, maka sama saja pengurus masjid telah melalaikan amanah.

Fenomena terkait pengelolaan keuangan masjid dalam bentuk dana hibah dapat kita lihat di Luwun Raya Makassar, dimana para mahasiswa mendesak Polda Sulsebar untuk segera menetapkan tersangka penyalahgunaan dana hibah masjid Agung Palapa. Mereka mempunyai dugaan yang kuat bahwa Yayasan Masjid Agung Palapa ini tidak mengelola dana hibah sebesar 5 Milyar dengan wajar dan transparan. Dana hibah 5 Milyar yang diselewengkan ini sangat merugikan Negara, karena tidak ada kejelasan dan transparansi dalam pengelolaan keuangan pada masjid ini sejak tahun diberikannya hibah yaitu sejak tahun 2008 hingga tahun 2015 (Movanita, 2017). Kasus ini sangat tidak sesuai dengan sifat entitas nirlaba keagamaan yang sangat lekat dengan sifat terbuka dan memegang amanah.

Penyimpangan dana masjid dapat diminimalisir dengan adanya pencatatan dan pembukuan yang baik yang didukung oleh penggunaan formulir yang bernomor urut tercetak, sehingga pernyalahgunaan dokumen juga dapat diminimalisir. Hal ini sesuai dengan tujuan pengendalian internal yaitu menghasilkan laporan keuangan yang handal, dipatuhinya kebijakan dan mendorong efisiensi.

Secara umum sumber dana yang diterima oleh Masjid sebagian besar diberikan oleh pihak eksternal berupa sedekah, infaq, hibah, bantuan pemerintah, bantuan swasta dan usaha ekonomi. Sumber dana masjid inilah yang menjadi pembeda masjid dengan entitas bisnis lainnya. Sebagai sebuah entitas nirlaba, semua dana masjid yang terkumpul ini nantinya akan diatur oleh pengurus masjid untuk mendanai seluruh kegiatan operasional masjid. Semakin besar dana dapat dikumpulkan, semakin banyak kegiatan yang dapat dilakukan, demikian pula sebaliknya (Sutarmadi, 2012:64).

Secara praktik, akuntabilitas pelaporan keuangan masjid pada umumnya hanya berupa pengumuman setelah pelaksanaan ibadah Jum'at, dimana pengurus masjid setempat akan membacakan rincian dana yang masuk ke kas masjid, dikeluarkan untuk keperluan apa saja serta memberitahu berapa jumlah saldo akhir dari dana yang dimiliki oleh masjid tersebut. Namun demikian tidak sedikit warga atau para jamaah masjid yang penasaran dengan aliran kas masuk dan kas keluar masjid, yang mana mereka turut andil menyumbangkan uang mereka. Pengumuman mengenai saldo kas akhir masjid sejauh ini dirasa cukup baik walaupun minim informasi, karena akan lebih baik lagi selain diumumkan setelah solat Jum'at juga dituangkan dalam bentuk laporan mingguan, bulanan atau bahkan tahunan agar bentuk akuntabilitas pengelolaan keuangan masjid menjadi lebih komprehensif. 
Pelaksanaan akuntabilitas di lingkungan organisasi publik dalam hal ini entitas keagamaan masjid, perlu diperhatikan prinsip-prinsip akuntabilitas yaitu sebagai berikut: (1) harus ada komitmen dari pimpinan dan seluruh anggota organisasi untuk melakukan pelaksanaan misi agar akuntabel; (2) harus merupakan suatu sistem yang dapat menjamin penggunaan sumber daya secara konsisten dengan peraturan perundang-undangan yang berlaku; (3) harus dapat menunjukkan tingkat pencapaian tujuan dan sasaran yang telah ditetapkan; (4) harus berorientasi pada pencapaian visi dan misi serta hasil dan manfaat yang diperoleh; (5) harus jujur, objektif, transparan dan inovasi sebagai katalisator perubahan manajemen organisasi dalam bentuk pemutakhiran metode dan teknik pengukuran kinerja dan penyusunan laporan akuntabilitas (Nurlailah dkk, 2014).

\section{METODE KEGIATAN}

Metode kegiatan yang digunakan meliputi:

1. Ceramah

Metode ceramah dilakukan di awal sebelum pelatihan dan pendampingan sebagai pengantar untuk membuat pembukuan sederhana karena tidak semua pengelola dana masjid adalah orang yang mengerti istilah-istilah dalam ekonomi/akuntansi. Sehingga dengan metode ini peserta pelatihan akan mendapatkan pengetahuan yang cukup dalam pengaplikasian pembukuan sederhana. Materi yang diberikan meliputi: pengertian pembukuan, manfaat pembukuan dan jenis pembukuan.

2. Pendampingan dalam membuat buku kas

Dengan metode ini pengelola dana masjid diberikan contoh dalam mengisi buku kas.

3. Membagikan buku kas dan formulir yang bernomor urut tercetak yang masih kosong untuk diisi dan dilanjutkan setelah pendampingan dilakukan.

\section{HASIL DAN PEMBAHASAN}

Di bawah ini faktor-faktor pendorong pelaksanaan pelatihan dan pendampingan, yaitu:

1. Terjalinnya kerjasama yang baik antara tim pengabdian dengan pengurus masjid yang berlokasi di Desa Midang Kecamatan Gunung Sari.

2. Selama pelaksanaan kegiatan pelatihan pengurus masjid yang berlokasi di Desa Midang Kecamatan Gunung Sari memberikan apresiasi yang baik.

Adapun factor yang menghambat pelaksanaan kegiatan pelatihan dan pendampingan adalah sulitnya menyatukan jadwal antara pengurus masjid yang berlokasi di Desa Midang Kecamatan Gunung Sari dengan tim pengabdian kepada masyarakat.. Namun, secara keseluruhan tidak ada hambatan yang terlalu teknis maupun administratif.

Berikut format buku kas dan formulir yang bernomor urut tercetak: 


\begin{tabular}{lllcc}
\hline Tanggal & \multicolumn{1}{c}{ Keterangan } & penrimaan & pengeluaran & saldo \\
\hline $1 / 1 / 2019$ & Saldo Awal & & & \\
& & & & $5,000,000$ \\
$1 / 4 / 2019$ & sumbangan masyarakat & $2,500,000$ & & $7,500,000$ \\
& membeli perlengkapan & & & \\
$1 / 7 / 2019$ & kebersihan & & $1,500,000$ & $6,000,000$ \\
& Saldo Akhir & & $6,000,000$ \\
\hline
\end{tabular}

MASJID MUHAJIRIN

BUMI SELAPARANG ASRI

Jln. Bromo No. 10

NO. 00001

BUKTI PENERIMAAN KAS

Tanggal:1/4/2019

\begin{tabular}{lll}
\hline NO & KETERANGAN & JUMLAH \\
\hline 1 & Sumbangan dari Masyarakt & 2.500 .000
\end{tabular}

Terbilang : Dua Juta Lima Ratus Ribu Rupiah

Diterima

Diberikan

Disetujui

MASJID MUHAJIRIN

BUMI SELAPARANG ASRI

Jln. Bromo No. 10

NO. 00001

BUKTI PENGELUARAN KAS

\begin{tabular}{|l|c|c|}
\hline \multicolumn{2}{|c|}{ Tanggal:1/7/2019 } \\
\hline NO & KETERANGAN & JUMLAH \\
\hline 1 & Perlengkapan kebersihan & 1.500 .000 \\
\hline & & \\
\hline & & 1.500 .000 \\
\hline \multicolumn{2}{|c|}{ TOTAL } \\
\hline
\end{tabular}

Terbilang : Satu juta lima ratus ribu rupiah 
Diterima Diberikan Disetujui

\section{KESIMPULAN DAN SARAN}

\section{Kesimpulan}

Melalui pelatihan dan pendampingan penggunaan buku kas dan formulir bernomor urut tercetak ini, pengurus masjid di desa Midang Kecamatan Gunung Sari dapat memahami dan diharapkan dapat mempraktikan pencatatan akuntansi sederhana atas setiap transaksi yang terjadi yang didukung oleh bukti transaksi yang memadai berupa formulir yang bernomor urut tercetak sehingga akuntabilitas pengelolaan keuangan masjid dapat dipertanggungjawabkan dan lebih dipercaya oleh masyarakat

\section{Saran}

Mengingat kegiatan ini hanya diadakan di satu desa saja, harapannya desa yang lain juga mendapatkan kesempatan yang sama untuk mengikuti pelatihan dan pendampingan. Alternative lain dapat melanjutkan kegiatan pelatihan dan pendampingan dengan dengan tema yang berbeda dan dengan dana yang lebih besar.

\section{UCAPAN TERIMA KASIH}

Kami mengucapkan terima kasih kepada Universitas Mataram yang telah memberi dukungan financial terhadap pengabdian ini.

\section{DAFTAR PUSTAKA}

Movanita, Ambaranie Nadia Kemala. 2017. Sylviana Diperiksa Kasus Masjid Al Fauz, Ini Penjelasan Polri. Kompasiana.com diakses melalui http://nasional.kompas.com/read/2017/01/30/13555591/sylviana.diperiksa.kasus.masjid .al.fauz.ini.penjelasan.polri pada 10 Mei 2018 pukul 7:54 WITA

Nurlailah., Nurleni., dan Madris. 2014. Akuntabilitas dan Keuangan Masjid di Kecamatan Tubo Sendana Kabupaten Majene. ASSETS, Volume 4, Nomor 2, Desember 2014 halaman 206-217. melalui http://repository.uksw.edu/bitstream/123456789/3714/2/T1_232009097_Full\%20text.p df diunduh pada 3 Desember 2018 pukul 00.17 WITA.

Sochimin. 2015. Praktik Manajemen Keuangan Masjid Berbasis Pemberdayaan Ekonomi Umat di Kota Purwokerto. Institut Agama Islam Negeri Purwokerto.

Sutarmadi, Ahmad. 2002. Visi, Misi dan Langkah Strategis Pengelolaan Masjid. Jakarta: Logos 